\title{
EFEITO DA SUPLEMENTAÇÃO COM SELÊNIO SOBRE A CONCENTRAÇÃO SÉRICA DE CREATINA KINASE EM BOVINOS
}

\author{
EFFECT OF THE SUPPLEMENTATION WITH SELENIUM ON SERUM CONCENTRATION \\ OF CREATINE KINASE IN CATTLE
}

\author{
Reis, L.S.L.S. ${ }^{1 *}$, S.B. Chiacchio ${ }^{2}$, P.E. Pardo ${ }^{3}$, R.T. Takahira ${ }^{2}$, R. Couto ${ }^{2}$, E. $\mathrm{Oba}^{4}$ \\ e S.N. Kronka ${ }^{3}$
}

${ }^{1}$ FMVZ. UNESP. Botucatu, SP. Brasil. *Correspondencia: Rua Osvaldo Cruz, 2027. Bairro Ouro Verde. Assis-SP. CEP 19800-081. Brasil. reis.Isls@gmail.com

2Departamento de Clínica Veterinária. FMVZ. UNESP. Botucatu, SP. Brasil.

${ }^{3}$ UNOESTE. Presidente Prudente, SP. Brasil.

${ }^{4}$ Departamento de Reprodução Animal e Radiologia. FMVZ. UNESP. Botucatu, SP. Brasil.

PalaVRAS CHAVE ADICIONAIS

CK. Sal mineral.

\section{RESUMO}

O estudo avaliou os efeitos da adição de diferentes concentrações de Se na mistura mineral sobre concentrações séricas de creatina quinase (CK) em bovinos. 60 bovinos da raça Nelore, machos, com aproximadamente 12 meses de idade, divididos aleatoriamente em 4 grupos de 15 bezerros: $G c, G_{36}, G_{54}$ e $G_{64}$ suplementados com $0 ; 3,6 ; 5,4$ ou $6,4 \mathrm{mg} \mathrm{Se/bovino/dia.} \mathrm{A}$ concentração sérica de $C K$, não sofreu efeito de interação concentração de selênio $x$ tempo, nem concentração de suplementação. Porém, independente da concentração de selênio na dieta, CK aumentou ao longo do tempo e a suplementação com $6,4 \mathrm{mg}$ Se elevou $(p<0,10)$ a freqüência de animais com CK acima da normalidade. A suplementação com selênio nas concentrações estudadas não reduz a concentração sérica de creatina quinase de bovinos, mas a suplementação diária com $6,4 \mathrm{mg}$ não é recomendada por ser possivelmente tóxica.

\section{SUMMARY}

The study, evaluated the addition of different concentrations of $\mathrm{Se}$ in mineral mixture affecting creatine kinase $(\mathrm{CK})$ serum concentrations in cattle. 60 male, Nellore cattle, at about 12 months old, were randomly assigned to groups ( 15 calves/ group), $\mathrm{Gc}, \mathrm{G}_{3,6}, \mathrm{G}_{5,4}$ or $\mathrm{G}_{6,4}(0,3.6,5.4$, and $6.4 \mathrm{mg}$

Recibido: 4-9-07. Aceptado: 17-1-08.

\section{AdDitionAL KEYWORDS}

CK. Mineral salt.

Se/bovine/day). The levels of serum $\mathrm{CK}$ in the cattle were not affected by neither the interaction selenium concentration $x$ time nor the concentration of supplementation. However, CK levels increased over the experiment irrespective of dietary selenium concentration. In addition, the frequency of animals with CK levels above normal increased $(p<0.10)$ in group $G_{6,4}$. The concentrations of selenium studied here do not affect serum CK in cattle, but the daily concentration of $6.4 \mathrm{mg}$ selenium is not recommended because it is possibly toxic effect.

\section{INTRODUÇÃO}

Deficiências de Se são comuns nas dietas de animais de produção. Dentre os efeitos dessa deficiência, destaca-se a miopatia esquelética e cardíaca crônica nos bovinos, conhecida como doença do músculo branco ou distrofia muscular nutricional, podendo atingir de $10 \%$ a $40 \%$ dos bezerros e causar mortalidade em todos os animais acometidos (Andrews, 1992).

A creatina kinase ( $\mathrm{CK}$ ) é enzima músculo-específica, altamente sensível e estável, associada à miopatias (Shpigel et al., 2003). A elevada concentração sanguínea dessa enzima é usada para diagnóstico da distro- 
fia muscular nutricional. Objetivou-se avaliar os efeitos de concentrações de Se administradas na mistura mineral sobre concentrações séricas de CK em bovinos.

\section{MATERIALE MÉTODOS}

O experimento foi conduzido no município de Lutécia, SP, Brasil. Utilizaram-se 60 bovinos, machos inteiros da raça Nelore (Bos taurus indicus), com aproximadamente 10 a 12 meses de idade, alimentados com Brachiaria decumbens e $B$. brizantha em sistema de pastejo extensivo. Estes animais foram divididos aleatoriamente em 4 grupos de 15 bovinos ( $\mathrm{Gc}, \mathrm{G}_{3,6}, \mathrm{G}_{54}$ e $\mathrm{G}_{6,4}$ ) que receberam suplementação de $0 ; 3,6 ; 5,4$ e 6,4 $\mathrm{mg}$ de Se/animal/dia (mistura mineral proteinada Top Line Recria ${ }^{\circledR}$, produzida por Matsuda Sementes e Nutrição Animal, Álvares Machado-SP, Brasil). Os suplementos minerais foram fornecidos aos bovinos em cocho de madeira localizados aproximadamente à 50 metros do bebedouro. Após 30 dias de ajuste ao novo suplemento mineral proteinado e as condições experimentais iniciaram-se o período experimental que duraram 120 dias.

Os piquetes utilizados eram semelhantes na topografia e composição botânica, sendo formados por $B$. decumbens (piquetes I, II e III) e $B$. brizantha (piquete IV). No dia 0 , recolheram-se amostras das forrageiras, cortadas à altura de pastejo e conservadas sob refrigeração a $-5^{\circ} \mathrm{C}$ para determinação da concentração de Se por meio da técnica de espectrofotometria de absorção atômica com forno de grafite.

Nos dias zero, 15, 30, 60, 90 e 120 colheram-se $10 \mathrm{ml}$ de sangue dos bovinos por meio da punção da veia jugular em tubos à vácuo sem anticoagulante, centrifugados a $2500 \mathrm{rpm}$ por 10 minutos e obteve-se as amostras de soro que foram armazenadas em freezer a $-20^{\circ} \mathrm{C}$ para determinação da concentração sérica de $\mathrm{CK}$ utilizando kits comerciais CK-NAC UV unitest y AA (Wiener lab, Rosario, Argentina) e quanti- ficadas em espectrofotômetro Celm SB 190. A CK é uma enzima músculo específica altamente estável e sensível as lesões musculares e sua dosagem ser utilizada no diagnóstico da distrofia muscular.

Os resultados obtidos foram submetidos à análise de variância pelo teste $\mathrm{F}$ e as médias comparadas pelo teste de Tukey. As freqüências de bovinos que apresentaram os níveis de CK acima do normal foram comparadas entre os grupos e entre os dias de observação por testes $\chi^{2}$. O nível crítico de significância foi estabelecido a $\alpha=5 \%$ (Banzatto y Kronka, 2006).

\section{RESULTADOSEDISCUSSÃO}

Os procedimentos experimentais comuns aos grupos testados garantiram a igualdade das condições gerais. A análise bromatológica das pastagens mostrou que ambos os tipos usados tinham concentrações idênticas de selênio ( $0,04 \mathrm{mg}$ de $\mathrm{Se} / \mathrm{kg}$ de matéria seca). Eram deficientes em selênio. Segundo o National Research Council (NRC, 1996), o nível selênio que atende às necessidades nutricionais de bovinos de corte é de $0,1 \mathrm{mg}$ de $\mathrm{Se} / \mathrm{kg}$ de matéria seca consumida. A condição dos animais também foi homogênea, visto que no primeiro dia experimental (dia $0)$ a concentração sérica de CK estava dentro da normalidade $(\mathrm{CK}=228 \mathrm{U} / 1)$ conforme estabelecido por Meyer y Harvey (1998) (figura 1). Assim, os resultados foram obtidos exclusivamente em função dos tratamentos.

As concentrações séricas de $\mathrm{CK}$ não diferiram entre os tratamentos (figura 2) e nem houve efeito da interação entre concentração de selênio e o tempo de experimento $\left(\mathrm{F}_{(15 ; 18)}=0,49, \mathrm{p}=0,94\right)$. Ao contrário, Hidiroglou et al. (1985) relataram que a suplementação com pellet de selênio intraruminal por 3 anos consecutivos reduziu a concentração de CK em bezerros. A diferença entre esse estudo e os dados aqui reportados pode advir do veículo de implementação do selênio e tempo de administração. 


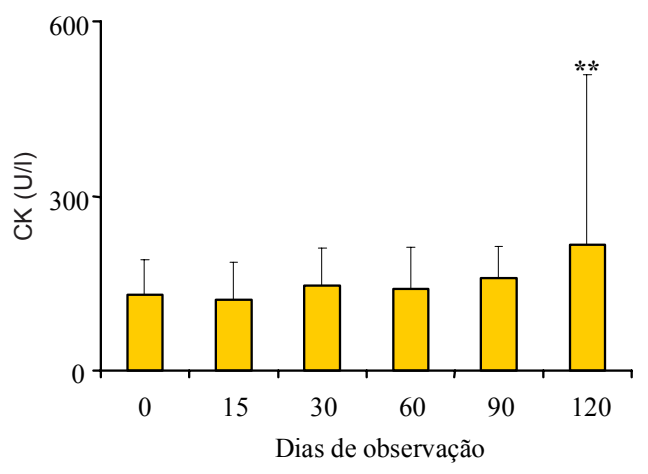

Figura 1. Concentração sérica de creatina kinase (CK) de bovinos recebendo suplementação com diferentes concentrações de selênio $\left(G c, G_{3,6} G_{5,4}\right.$ e $G_{64}$ ) ao longo de 120 dias de experimento. ${ }^{*} *$ indica diferença significativa entre os dias de observação $\left(F_{(5: 280)}=4,05, p<0,01\right)$. (Serum concentration of creatinine kinase (CK) in cattle receiving different concentrations of selenium supplementation (Gc, $\mathrm{G}_{3,6}, \mathrm{G}_{5,4}$ and $\mathrm{G} 6,4$ ) over 120 days of experiment. $* *$ indicates significant difference among the observation days $\left(F_{(5 ; 280)}=4.05, p<0.01\right)$.

Dentre as possíveis causas da falta de resposta observada no presente experimento, podem ser destacadas: a) grande variabilidade de CK, diminuindo a sensibilidade de avaliação da resposta ao selênio suplementar; e b) as reservas iniciais de selênio no fígado dos novilhos, associadas ao período experimental relativamente curto (150 dias), poderiam mascarar a resposta à suplementação de selênio por certo tempo.

$\mathrm{O}$ aumento significativo $(\mathrm{p}<0,01)$ na concentração sérica de CK no último dia de observação (dia 120), independentemente da suplementação com Se (figura 1), provavelmente foi conseqüência do grande número de bezerros (13) com CK acima da normalidade no final do experimento (tabela I). Embora a avaliação da freqüência de animais com concentração sérica de CK acima da normalidade fosse similar entre os grupos, na comparação temporal, observase que o grupo $G_{64}$ não teve aumento significativo $(p>0,05)$ na freqüência de be- zerros com CK acima do normal no dia 120 (tabela I).

Ainda que qualquer sinal de intoxicação clínica por Se não tenha sido detectado, é possível que tenha ocorrido intoxicação subclínica, que provavelmente causou lesão muscular (degeneração muscular) com conseqüente aumento das concentrações de CK (McDowell, 1992), no grupo $\mathrm{G}_{6,4}$ que recebeu a suplementação diária de $6,4 \mathrm{mg}$ por 120 dias, que corresponde a cerca de $1,79 \mathrm{mg} \mathrm{Se} / \mathrm{kg}$ de matéria seca. O NRC (1996) indica como maior concentração tolerável de Se na dieta $2 \mathrm{mg} / \mathrm{kg}$, e relata que pode ocorrer intoxicação crônica por Se em bovinos quando consumindo dietas contendo concentrações de Se acima de $5 \mathrm{mg} / \mathrm{kg}$. Entretanto, dependendo das condições, as quantidades de Se capazes de provocarem alterações são menores. O fornecimento de dieta com $0,8 \mathrm{mg} / \mathrm{kg}$ de Se (na forma de selenito de sódio) provocou intoxicação crônica em novilhos (O'Toole e Raisbeck, 1995). Assim, a suplementação de Se na dose diária de $6,4 \mathrm{mg}$ por 120 dias é indesejável para os bovinos.

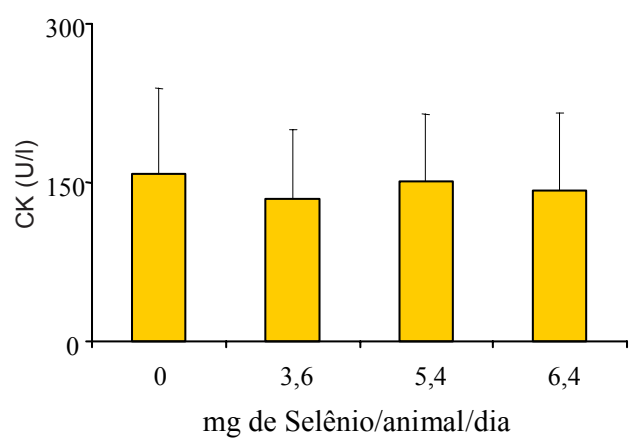

Figura 2. Efeito da suplementação com 0 $(G c), 3,6\left(G_{3,6}\right), 5,4\left(G_{5,4}\right)$ e 6,4 $\left(G_{6,4}\right) m g d e$ selênio/bovino/dia na concentraçào sérica de creatina kinase (CK) dos bovinos. Não há diferença entre os tratamentos $\left(F_{(3.56)}=1,19\right.$; $p>0,05$ ). (Effect of daily selenium supplementation at $0(\mathrm{Gc}), 3.6\left(\mathrm{G}_{36}\right), 5.4\left(\mathrm{G}_{54}\right)$ and $6.4\left(\mathrm{G}_{6,4}\right) \mathrm{mg}$ on serum creatinine kinase (CK) in cattle. The groups were not different $\left(F_{(3 ; 56)}=1.19 ; p>0.05\right)$. 
REIS, CHIACCHIO, PARDO, TAKAHIRA, COUTO, OBAE KRONKA

Tabela I. Freqüencia de bovinos que apresentaram concentração sérica de cretina kinase $(C K)$ acima do normal $(C K>228 \mathrm{U} / \mathrm{l})$. (Frequency of cattle with serum concentration of creatinine kinase $(C K)$ above the normal values $(C K>228 \mathrm{U} / \mathrm{I}))$.

\begin{tabular}{lccccccc}
\hline & \multicolumn{7}{c}{ Dias de observação } \\
Grupos & 0 & 15 & 30 & 60 & 90 & 120 & \multirow{2}{*}{$\chi^{2}$ (dias) } \\
\cline { 2 - 6 } $\mathrm{G}_{3,6}$ & 1 & 1 & 1 & 2 & 2 & 3 & $2,00^{\text {ns }}$ \\
$\mathrm{G}_{5,4}$ & 1 & 0 & 2 & 0 & 2 & 4 & $7,66^{\text {ns }}$ \\
$\mathrm{G}_{6,4}$ & 0 & 3 & 1 & 1 & 4 & 1 & $6,80^{\text {ns }}$ \\
$\chi^{2}$ (grupos) & 1 & 2 & 1 & 0 & 1 & 5 & $9,20^{*}$ \\
\hline
\end{tabular}

*Indica diferença significativa $(p<0,05)$ entre os dias num mesmo grupo.

O grupo $\mathrm{G}_{5,4}$ suplementado com $5,4 \mathrm{mg}$ de Se/animal/dia, apresentou a menor freqüência de animais com lesão muscular (CK $>228$ UI) no dia 120 sendo $300 \%$ e $400 \%$ menor em relação aos grupos $\mathrm{Gc}$ e $\mathrm{G}_{3,6}$, respectivamente. Mesmo assim, não houve diferença significativa $(\mathrm{p}>0,05)$ entre os grupos (tabela I). Portanto, esta suplementação com Se não provocou sinais clínicos nem subclínicos de intoxicação.

A suplementação com selênio nas

\section{BIBLIOGRAFIA}

Andrews, A.H. 1992. Other calf problems. In: Andrews A.H., R.W. Blowey, H. Boyd and R.G. Eddy (eds). Bovine medicine. Blackwell Scientific Publications. London. p. 213-228.

Banzatto, D.A. e S.N. Kronka. 2006. Experimentação agrícola. FUNEP. Jaboticabal. 237 p.

Hidiroglou, M., J. Proulx and J. Jolette. 1985. Intraruminal selenium for control of nutritional muscular distrophy in cattle. J. Dairy Sci., 68: 57-66.

McDowell, L.R. 1992. Selenium. In: McDowell, L.R. (eds). Minerals in animal and human nutrition. Academic Press. San Diego New York Boston. p. 294-332.

Meyer, D.J. and J.W. Harvey. 1998. Veterinary laboratory medicine. Interpretation \& diagnosis. W.B. Saunders. Philadelphia. 349 p. concentrações estudadas não reduz a concentração sérica de creatina kinase de bovinos. Porém, a suplementação diária de selênio de 6,4 mg é indesejada por ser possivelmente tóxica nas condições estudadas.

\section{AGRADECIMENTOS}

A Matsuda Sementes e Nutrição Animal, Álvares Machado, SP, Brasil pelo apoio, incentivo e patrocínio desta pesquisa.

Morais, S.S. 2001. Importância da suplementação mineral para bovinos de corte. Documento $\mathrm{n}$. 114. Embrapa CNPGC. Campo Grande. p. 26.

NRC. 1996. Minerals. In: National Research Council (eds). Nutrient requirements of beef cattle. National Academy Press. Washington. p. 5474.

O'Toole, D. and M.F. Raisbeck. 1995. Pathology of experimentally induced chronic selenosis (alkali disease) in yearling cattle. J. Vet. Diagn. Invest., 7: 364-3735.

Shpigel, N.Y., Y. Avidar and E. Bogin. 2003. Value of measurements of the serum activities of creatine phosphokinase, aspartate aminotransferase and lactate dehydrogenase for predicting whether recumbent dairy cows will recover. Vet. Rec., 152: 773-776. 